\title{
Chitin determination on marine seston in a shallow temperate estuary (Argentina)
}

\author{
Florencia Biancalana ${ }^{*}$, Germán Kopprio ${ }^{1}$, M. Sofia Dutto ${ }^{1}$, Anabela A. Berasategui ${ }^{1}$, \\ Anna Fricke ${ }^{1}$, John E. Garzón-Cardona ${ }^{2}$, Dieter Peterke ${ }^{3}$, Rubén Lara ${ }^{1,3}$
}

\author{
${ }^{1}$ Consejo Nacional de Investigaciones Científicas y Técnicas, Instituto Argentino de Oceanografía. \\ (Florida 4750, B8000FWB Bahía Blanca, Argentina) \\ ${ }^{2}$ Instituto de química del Sur, Universidad Nacional del Sur \\ (Av. Alem 1253, B8000CPB Bahía Blanca) \\ ${ }^{3}$ Leibniz Center for Tropical Marine Ecology (ZMT) \\ (Fahrenheitstr. 6, 28359 Bremen, Germany) \\ *Corresponding author: biancaf@criba.edu.ar
}

\begin{abstract}
Chitin is one of the most abundant biopolymers in the planet. Chitin was quantified in seston fractions in order to obtain the first characterization of this polymer in the Bahía Blanca Estuary. Sampling was conducted at two sites: a non- impacted tidal channel -Bahía del Medio (BM)- and a sewage discharge sector -Canal Vieja (CV)-, during winter and summer. The highest values of chitin were observed in the seston fraction $<20 \mu \mathrm{m}\left(6.1 \mathrm{mg} \mathrm{L}^{-1}\right.$ in $\mathrm{BM}$ in summer). The remaining larger fractions $(20-60,60-$ $200,200-500$ and $>500 \mu \mathrm{m}$ ) did not exceed $\sim 1 \%$ of total chitin. . The higher concentration of chitin in seston $<20 \mu \mathrm{m}$ suggests that this fraction is a large reservoir of this biopolymer contributing to organic matter for microorganisms in the food web of the Bahía Blanca Estuary. This study is also the first report on the possible sources of chitin in Argentina marine ecosystems.
\end{abstract}

Descriptors: Seston fractions, Chitin sources, Bahía Blanca estuary.

\section{Resumo}

A quitina é um dos biopolímeros mais abundantes no planeta. A quitina foi quantificada em frações do seston, com a finalidade de obter a primeira caracterização deste polímero no Estuário de Bahía Blanca. A amostragem foi realizada durante o inverno e o verão em dois locais: em um canal de maré não impactado (Bahía del Medio, BM) e em um setor de descarga de esgoto (Canal Vieja, CV). Os maiores valores de quitina foram observados na fração seston $<20 \mu \mathrm{M}\left(6,1 \mathrm{mg} \mathrm{L}^{-1}\right.$ em BM no verão). As frações remanescentes (20-60, $60-200,200-500$ e $>500 \mu \mathrm{M}$ ) não excederam $\sim 1 \%$ de quitina total. A maior concentração de quitina no seston $<20 \mu \mathrm{M}$ sugere que essa fração é um grande reservatório deste biopolímero, contribuindo para a matéria orgânica para os microorganismos na cadeia alimentar do Estuário de Bahía Blanca. Este é o primeiro estudo sobre as possíveis fontes de quitina em ecossistemas marinhos na Argentina.

Descritores: Frações seston, Fontes de quitina, Estuário de Bahía Blanca. 


\section{INTRODUCTION}

Chitin is one of the most important polysaccharides in marine ecosystems (MONTGOMERY et al., 1990; SOUZA et al., 2011). Studies on the determination and quantification of chitin in the marine environment have shown that its principal producers are within the zooplankton, specially euphausiids and copepods (JEUNIAUX; VOSS-FOUCART, 1991; NICOL; HOSIE, 1993). However, the estimation of chitin is not only based on the production of chitin by copepods (exoskeletons) and their abundance (JOHNSTONE, 1908) but also on zooplankton fecal pellets (YOSHIKOSHI; KÔ, 1988). There are also some genus of diatoms, such as Thalassiosira and Skeletonema, which produce this polymer (SMUCKER; DAWSON, 1986). This polymer is also present in cell walls of fungi, yeast, in cyst walls of some ciliates and amoebae; and in the lorica walls of some ciliates (GOODAY, 1990).

A continual rain of chitin is deposited on the ocean floor, being formed by dynamic processes, such as molting cuticles and senescence of planktonic organisms. This chitin supply is part of particulate aggregates known as "marine snow" (ALLDREDGE; SILVER, 1988; ALLDREDGE; GOTSCHALK, 1990). Despite the continuous deposition of this highly insoluble polymer, low amounts of it are found on the ocean sediments (LARA et al., 2011). This phenomenon is probably the result of chitinolytic activity of bacteria, which is responsible for the recycling process of chitin present in the marine environment (ZOBELL; RITTENBERG，1938; KIRCHMAN; WHITE， 1999; TANG et al., 2010).

In the Bahía Blanca Estuary (BBE) relatively high suspended particulate matter (SPM) loads (yearly average $77.6 \mathrm{mg} \mathrm{L}^{-1}$ ) are produced by the action of tides and wind, principal factors controlling the resuspension and transport of SPM from the bottom and the coast in this system (GUINDER et al., 2009; MENÉNDEZ et al., 2012). Particulate organic matter (POM) constituted more than half of the total SPM concentration during the phytoplankton bloom in BBE in winter (GUINDER et al., 2009). During the rest of the year, detritus appears to play an important role as food for filter feeders (DIODATO; HOFFMEYER, 2008). High allochthonous and autochthonous detritus and nanophytoplankton biomass are part of the natural diet of zooplankton that feed several commercial fish species in BBE (DIODATO; HOFFMEYER, 2008;
GUINDER et al., 2009). However, little is known about chitin concentration and its production by plankton and their contribution to the micro-detritus with exuviae and pellets in this ecosystem.

In this context, the aim of this research was to determinate the chitin amount in different seston size fractions and obtain a first appraisal of possible sources of this biopolymer to marine seston in the Bahía Blanca Estuary system.

\section{MATERIAL AND METHODS}

BBE is located in the southwest of the Buenos Aires Province in Argentina $\left(38^{\circ} 44^{\prime}-39^{\circ} 27^{\prime} \mathrm{S}\right.$ and $61^{\circ} 45^{\prime}-62^{\circ}$ $30^{\prime} \mathrm{W}$ ) (Figure 1). It is formed by several tidal channels, islands, extensive tidal flats and marshes, covering $\sim 2,300$ $\mathrm{km}^{2}$ (PERILLO et al., 2001). The main channel (Canal Principal, Figure 1), has a total length of $60 \mathrm{Km}$ with a depth of $22 \mathrm{~m}$ at the mouth (3-4 $\mathrm{km}$ width) to $3 \mathrm{~m}$ at the head (200 m width) (PERILLO; PICCOLO, 1991). Water circulation is dominated by a quasi-stationary, semidiurnal tidal wave (PICCOLO, 2008). The most frequent winds are from the N-NW. Winds from the S-SW, which bring rain and fog, are less common (PERILLO et al., 2001). $\mathrm{BBE}$ waters can reach high turbidities (maximum value $240 \mathrm{mg} \mathrm{L}^{-1}$ ) caused by strong currents that favor the resuspension of fine sediments (silt, clay and sand), which contribute to the inorganic fraction of SPM (FEDERICI et al., 2004).

In the inner zone, BBE is characterized as a partially mixed estuary with a strong tendency to become vertically homogeneous during low runoff conditions (PERILLO et al., 2001). The Sauce Chico River and the Napostà Grande Stream are the most important freshwater tributaries that flow into the BBE from the northern end shore (PICCOLO, 2008). Human activities, petrochemical and chemical industries, and harbors produce an impact particularly on the northern sector of the BBE (ARIAS et al., 2010; FERNÁNDEZ-SEVERINI et al., 2009).

Two sampling sites were selected (Figure 1): Canal Vieja $(\mathrm{CV})$, which receives untreated sewage from the city of Bahía Blanca (TOMBESI et al., 2000), and Bahía del Medio (BM) a tidal channel not impacted by human or industrial waste. Bacteriological studies indicated that the water quality of BM is suitable for aquiculture activity (BALDINI et al., 1999), whereas in CV the presence of Escherichia coli indicates fecal contamination (BALDINI; CABEZALI, 1988; CABEZALI et al., 1994). 


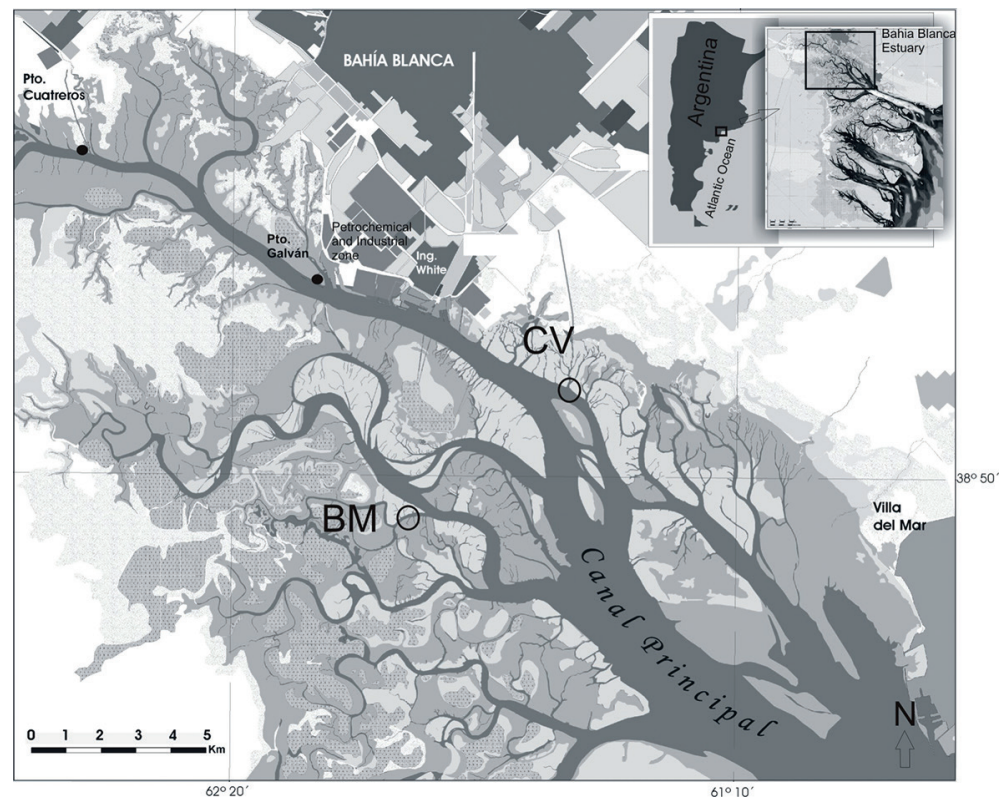

Figure 1. Map of the Bahía Blanca Estuary showing the sampling sites: Canal Vieja (impacted site-CV) and Bahía del Medio (non-impacted site-BM).

Four sampling campaigns were carried out in December 2008 and February 2009 (summer), and July and August 2009 (winter). Water samples were collected at the surface using a $5 \mathrm{~L}$ Van Dorn bottle and filtered with $20 \mu \mathrm{m}$ net to obtain seston size fraction $<20 \mu \mathrm{m}$. Additionally, horizontal tows were carried out in the upper layer (0-2 m) during the mid-ebb tide, using 20, 200 and $500 \mu \mathrm{m}$-mesh nets from a motor boat at a speed of 2 knots. The seston samples obtained with the $20 \mu \mathrm{m}$ net were first fractioned with a $200 \mu \mathrm{m}$ filter to obtain the $20-200 \mu \mathrm{m}$ fraction. This material was further filtered by a mesh of $60 \mu \mathrm{m}$ size to separate it into $20-60 \mu \mathrm{m}$ and $60-200 \mu \mathrm{m}$ fractions (DI MAURO et al., 2009). The concentrates obtained by $200 \mu \mathrm{m}$ mesh net were passed through a 500 $\mu \mathrm{m}$ net to get the 200-500 $\mu \mathrm{m}$ fractions.

Temperature and salinity were registered at the same time of tows with an HORIBA U-10 multiparameter probe. Additionally, surface water samples were taken to determine chlorophyll $a$ ( $\mathrm{Chl} a$ ), phaeopigments and particulate organic carbon of total seston (POC-TS, $\mu \mathrm{M}$ ). These analyses were done by the Marine Chemistry Laboratory at IADO following STRICKLAND; PARSONS (1968). The physicochemical and biological characteristics of the waters in $\mathrm{CV}$ and $\mathrm{BM}$, which used in this study, were the same described in detail by DUTTO et al. (2012).

Seston samples were vacuum-filtered using glass fiber filters (GF/F $-0.7 \mu \mathrm{m}$ pore) precombusted at $450{ }^{\circ} \mathrm{C}$ during 4 hours. After filtration, filters were dried at $50{ }^{\circ} \mathrm{C}$ during 12 hours. In each seston size fraction, particulate organic carbon was determined after removing inorganic $\mathrm{C}$ by acidification with $1 \mathrm{~N} \mathrm{HCl}$. POC was quantified with an elemental analyzer (Fisons, NA 2100) at the Leibniz Centre for Tropical Marine Ecology, Bremen, Germany. Standard Reference Material 1515 was used for calibration and as a quality standard.

SPM (mg L-1) was determined gravimetrically after drying at $50{ }^{\circ} \mathrm{C}$ to constant weight. Chitin content was measured by the WGA-FITC method after MONTGOMERY et al. (1990). WGA (wheat germ agglutinin) has a high affinity for $\mathrm{N}$-acetyl glucosamine residues, which is a component of chitin, and binds specifically to it even when samples contain high concentrations of cellulose, clay, and bacteria (MONTGOMERY et al. 1990). The method was calibrated with purified crab chitin (Sigma-Aldrich, St Louis, MO, USA) as standard, quantified by fluorimetric measurement of excess WGA after its reaction with fluorescein isocyathionate (FITC).

Non-parametric statistical procedures were applied due to data did not meet the assumptions of normality and homoscedasticity. The Mann-Whitney U-test was used to determine differences on chitin concentration between sites and seasons. This analysis was conducted at a significant level of 0.05 using SPSS 15.0 software. The Spearman's rank correlation coefficients were calculated to determine 
the degree of association among chitin concentration, POC, SPM from CV and BM stations ( $\mathrm{n}=20)$, POC-TS and environmental variables (temperature, salinity, Chl $a$ and phaeopigments, $\mathrm{n}=8$ ), using SPSS 15.0 software.

\section{RESULTS}

Highest values of chitin were found in the seston fraction $<20 \mu \mathrm{m}$ (Figure 2). In $\mathrm{CV}$, chitin fluctuated between $1.2 \mathrm{mg} \mathrm{L}^{-1}$ in summer (February 2009) and "no detected" values (winter) (Figure 2). In BM, chitin ranged between $6.1 \mathrm{mg} \mathrm{L}^{-1}$ in summer (December 2008) and $4.2 \mathrm{mg} \mathrm{L}^{-1}$ in winter (July 2009) (Figure 2). In both seasons, more than $\sim 99 \%$ of chitin occurred in the fraction $<20 \mu \mathrm{m}$ and the remaining $\sim 1 \%$ was distributed among the other fractions (Figure 3). In the $20-60 \mu \mathrm{m}$ fraction, chitin reached $2.310^{-3} \mathrm{mg} \mathrm{L}^{-1}$ in CV in July 2009 and 4.0
$10^{-3} \mathrm{mg} \mathrm{L}^{-1}$ in BM in December 2008 (Figure 2). In the fraction $60-200 \mu \mathrm{m}$ the maximum value of $1.210^{-3} \mathrm{mg} \mathrm{L}^{-1}$ were registered in CV in December 2008; in the 200-500 $\mu \mathrm{m}$ fraction: $0.610^{-4} \mathrm{mg} \mathrm{L}^{-1}$ in $\mathrm{CV}$ in December 2009 and in the fraction $>500 \mu \mathrm{m}: 0.0610^{-4} \mathrm{mg} \mathrm{L}^{-1}$ in BM in December 2009 (Figure 2).

Both, SPM and POC presented the same pattern of chitin decreasing their values from the $<20 \mu \mathrm{m}$ fraction to the remaining fractions (Figure 2 and 3 ). The maximum SPM were registered in fraction $<20$ $\mu \mathrm{m}$, reaching $182.1 \mathrm{mg} \mathrm{L}^{-1}$ in $\mathrm{CV}$ in winter (July 2009) and $232.1 \mathrm{mg} \mathrm{L}^{-1}$ in BM in winter (July 2009) (Figure 2). The maximum POC was $177.7 \mu \mathrm{M}$ in $\mathrm{CV}$ in winter (July 2009) and $242 \mu \mathrm{M}$ in BM in summer (February 2009 ) in the $<20 \mu \mathrm{m}$ fraction (Figure 2). SPM in the remaining fractions did not exceed $0.24 \mathrm{mg} \mathrm{L}^{-1}(>500$
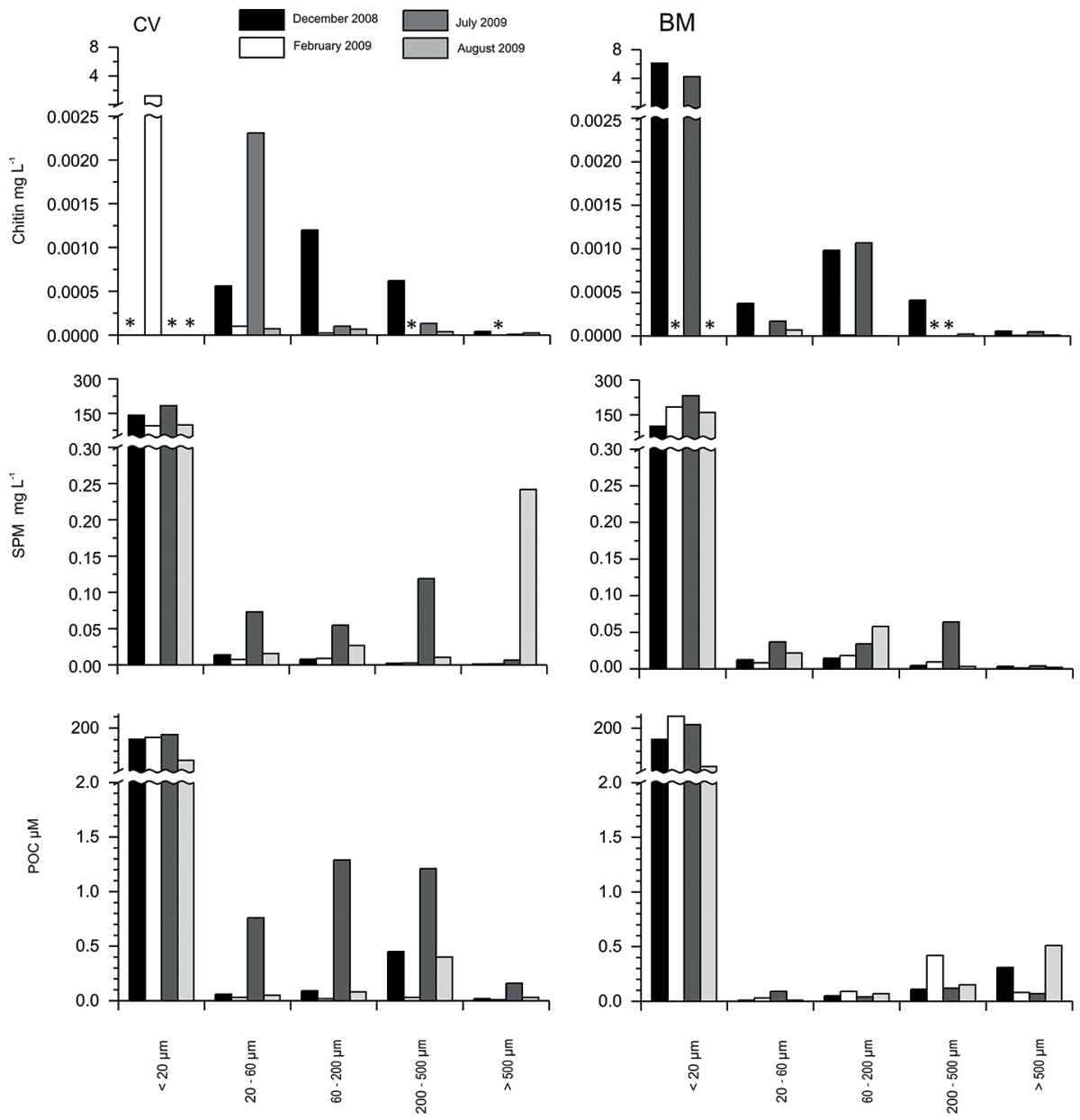

SESTON SIZE FRACTIONS

Figure 2. The concentration of chitin, SPM and POC in seston size fractions, in both sampling sites (CV and BM) during summer (December 2008-February 2009) and winter (July and August 2009). * not detected values of chitin. 


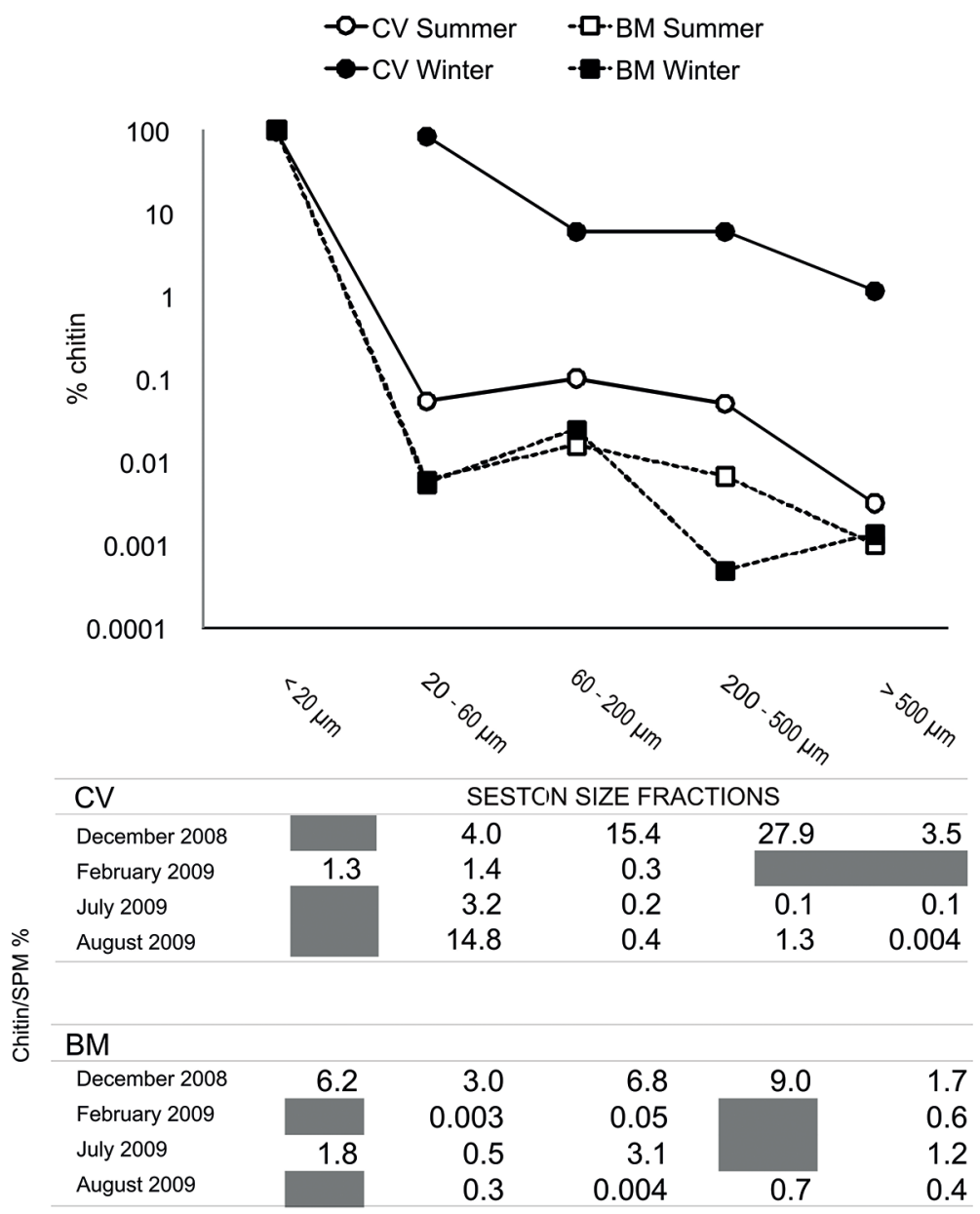

Figure 3. Chitin concentration in the seston size fractions expressed in percentage, corresponding to $\mathrm{CV}$ and $\mathrm{BM}$ during summer and winter ( $\mathrm{Y}$ axis expressed in logarithmic scale). The proportion of chitin in SPM (\%) of seston size fractions calculated in both sampling sites during summer and winter.

$\mu \mathrm{m})$ in $\mathrm{CV}$ (August 2009) and $0.06 \mathrm{mg} \mathrm{L}^{-1}(60-200$, 200-500 $\mu \mathrm{m}$ ) in BM during winter (July and August 2009). POC in the larger fractions reached a maximum of $1.3 \mu \mathrm{M}(60-200 \mu \mathrm{m})$ in CV in July 2009 and $0.5 \mu \mathrm{M}$ $(>500 \mu \mathrm{m})$ in BM in August 2009.

The proportion of chitin in SPM $(\mathrm{w} / \mathrm{w})<20 \mu \mathrm{m}$, ranged from 1.8 to $6.2 \%$ in BM (July 2009 and December 2008, respectively), and in CV it reached a maximum of $1.3 \%$ (February 2009) (Figure 3). The proportion of chitin in SPM $(\mathrm{w} / \mathrm{w})$ in the 20-60 $\mu \mathrm{m}$ and in the $60-200$ $\mu \mathrm{m}$ fractions, reached $\sim 15 \%$ in CV (August 2009 and December 2008, respectively) (Figure 3). The proportion of chitin in SPM (w/w) reached $\sim 28 \%$ and $\sim 4$ in seston fractions of $200-500 \mu \mathrm{m}$ and $>500 \mu \mathrm{m}$ in CV (December 2008), respectively (Figure 3).
No difference was detected between chitin concentrations in summer and in winter (Mann-Whitney test, $\mathrm{U}=190, p=0.78$ ). Further, no difference was detected between chitin concentration from $\mathrm{CV}$ and $\mathrm{BM}$ stations (Mann-Whitney test, $\mathrm{U}=191, p=0.80$ ).

Environmental variables were shown in Table 1. The only Spearman's rank highly significant positive correlation detected in CV was between POC and SPM $(\mathrm{r}=0.73, \mathrm{n}=20, p<0.01) \quad($ Table 2). At the same time the concentration of SPM was significantly negatively correlated with phaeopigments $(\mathrm{r}=-0.80, \mathrm{n}=8, p<0.05)$ (Table 2). In BM, chitin concentration were significantly positively correlated with POC-TS $(\mathrm{r}=0.78, \mathrm{n}=8, p<0.05)$ (Table 2). The SPM concentration was significantly negatively correlated with Chlorophyll $a(\mathrm{r}=-0.79, \mathrm{n}=8$, 
Table 1. Environmental and biotic variables (mean $\pm \mathrm{SE}$ ) of two sampling sites at the BBE during summer and winter.

\begin{tabular}{lcccc}
\hline & \multicolumn{2}{c}{ Canal Vieja } & \multicolumn{2}{c}{ Bahia del Medio } \\
Environmental Variables & Summer & Winter & Summer & Winter \\
\hline Temperature $\left({ }^{\circ} \mathrm{C}\right)$ & $23.34 \pm 0.90$ & $12.20 \pm 0.68$ & $23.82 \pm 0.28$ & $9.53 \pm 0.96$ \\
Salinity & $21.45 \pm 6.63$ & $38.78 \pm 0.16$ & $38.85 \pm 0.03$ & $39.20 \pm 0.08$ \\
Chl $a\left(\mu \mathrm{g} \mathrm{L}^{-1}\right)$ & $8.50 \pm 0.93$ & $8.25 \pm 1.66$ & $10.21 \pm 0.93$ & $5.36 \pm 0.88$ \\
Phaeopigment $\left(\mu \mathrm{g} \mathrm{L}^{-1}\right)$ & $3.77 \pm 1.55$ & $5.24 \pm 1.30$ & $6.90 \pm 1.21$ & $8.85 \pm 2.85$ \\
POC-TS $(\mu \mathrm{M})$ & $318.13 \pm 37.19$ & $277.52 \pm 13.23$ & $343.19 \pm 48.27$ & $239.20 \pm 34.19$ \\
\hline
\end{tabular}

Table 2. The Spearman's rank correlation coefficients among chitin concentration, POC, SPM from CV and BM stations $(n=20)$, POC-TS and environmental variables $(\mathrm{n}=8) .{ }^{*} p<0.05$ significant difference; $* * p<0.01$ high significant difference

\begin{tabular}{|c|c|c|c|}
\hline \multicolumn{4}{|c|}{ Spearman's rank correlation coefficients } \\
\hline Stations & & Rho the Spearman & $\mathrm{n}$ \\
\hline \multicolumn{4}{|l|}{$\mathrm{CV}$} \\
\hline POC & SPM & $0.73 * *$ & 20 \\
\hline SPM & Phaeopigment & $-0.80 *$ & 8 \\
\hline \multicolumn{4}{|l|}{$\mathrm{BM}$} \\
\hline Chitin concentration & POC-TS & $0.79 *$ & 8 \\
\hline \multirow{2}{*}{ SPM } & Chlorophyll $a$ & $-0.79 *$ & 8 \\
\hline & Phaeopigment & $-0.80^{*}$ & 8 \\
\hline
\end{tabular}

$p<0.05)$ and with phaeopigments $(\mathrm{r}=-0.80, \mathrm{n}=8, p<0.05)$ (Table 2).

\section{DISCUSION}

In this study the highest values of chitin were found in the seston fraction $<20 \mu \mathrm{m}$ and the larger fractions were less of $\sim 1 \%$ of total chitin. SPM followed the same pattern of chitin decreasing from fraction $<20 \mu \mathrm{m}$ to the other size fractions. Similarly, LARA et al. (2011) reported the highest chitin values in the size fraction $<20 \mu \mathrm{m}$, ranging from 1 to $2 \mathrm{mg} \mathrm{L}^{-1}$ (97\% of total chitin). This accounted on average to $1.6 \%(\mathrm{w} / \mathrm{w})$ of SPM, correlating with the highest abundance of bacteria belonging to Vibrio spp. in waters of the Sunderban mangrove. Additionally, the remaining chitin (less than 3\%) corresponded to other size fractions composed by microphytoplankton $(>60 \mu \mathrm{m})$ and mesozooplankton (LARA et al., 2011).

Regarding the composition of the fraction size $<20$ $\mu \mathrm{m}$, detritus as well as pico- and nanoplancton seem to be important components as primary links in the detritivore chain in BBE (DIODATO; HOFFMEYER, 2008; DUTTO et al., 2012). In these size classes, bacterial structures and fungi contributed to chitin production (GOODAY, 1990).
Moreover, both fungi and bacteria have been indicated as a potential contributors to chitin in size fraction $<20 \mu \mathrm{m}$ of seston (LARA et al., 2011) together with small diatoms (5 to $\sim 20 \mu \mathrm{m}$ ) and zooplankton exoskeletons including exuviae, and faecal pellets (micro-detritus) (GOODAY, 1990; VOLKMAN; TANOUE, 2002; LARA et al., 2011). Thus, in this study, the chitin concentration determined in size fraction $<20 \mu \mathrm{m}$ of seston might proceed from fungi and some structure of bacteria, small phytoplankton and micro-detritus.

The association between POC and SPM in CV, and chitin concentration with POC-TS in BM strongly indicate that planktonic and detrital material contributed to chitin pool in the BBE. Additionally, SPM was negatively associated with phaeopigments, which were the product of chlorophyll $a$ degradation and indicator of zooplankton grazing (BIANCALANA et al., 2012; DUTTO et al., 2012; SPETTER et al., 2015), contributed to the fraction $<20 \mu \mathrm{m}$ of SPM in both stations. Dynamic processes such as cuticles molting and senescence of planktonic organisms, resulting in a continuous supply of chitin to the marine environment (ALLDREDGE; GOTSCHALK, 1990), might also contributed to chitin pool in the fraction $<20 \mu \mathrm{m}$ SPM in this system.

Although fungi and bacteria were not measured in this work, both are involved in the production of chitin (KIRCHMAN; WHITE, 1999; TANG et al., 2010; WURZBACHER et al., 2010). Moreover, terrestrial and marine heterotrophic aerobic bacteria have been found in CV and BM (CABEZALI et al., 1994; BALDINI et al., 1999).

Both sites were characterized by high total organic carbon from different antropic and other allochthonous sources (DUTTO et al., 2012; HOFFMEYER; BARRÍA DE CAO, 2007). CV received untreated sewage from the duct collector of Bahía Blanca city with a great amount of sediment and detritus contribution, which is consequence of the freshwater input and sewage (DUTTO et al., 2012). The non-impacted site, BM, was surrounded by 
tidal flats covered by Spartina alterniflora, indicating an important supply of particular organic matter from these salt marshes. Fungi and bacteria organisms are involved in Spartina decomposition and its detritus inputs contributed to the organic matter (LEE et al., 1980; MENÉNDEZ; SANMARTIN, 2007).

Diatom blooms are the most important event of primary biomass production during winter and early spring (POPOVICH et al., 2008). They are characterized by the genus Thalassiosira (diameter 15-46 $\mu \mathrm{m}$ ), commonly found throughout the year, but especially in winter in BBE (PETTIGROSSO; POPOVICH, 2009; GUINDER et al., 2009). It is known that several common genera of diatoms, such as Thalassiosira and Skeletonema, produce chitin as an important portion of their biomass (e.g. 34-38\% of chitin in total cultured of $T$. fluviatilis, including frustules) (SMUCKER; DAWSON, 1986; SMUCKER, 1991). In this context and taking into account that in this study the highest chitin concentration was observed on seston size fraction of 20-60 $\mu \mathrm{m}$ in CV during winter (July), we assume that the chitin concentration found in this fraction size belonged to diatoms.

On the other hand, the 60-200 $\mu \mathrm{m}$ fraction, in which microzooplankton is included, showed a higher concentration on summer. In BBE, microzooplankton is composed by Tintinnids (loricated ciliate $>28$ to $100 \mu \mathrm{m}$ ) and naked ciliates (BARRÍA DE CAO et al., 2003; BARRÍA DE CAO et al., 2005; PETTIGROSSO; POPOVICH, 2009). Tintinnids showed different peaks throughout the year, but their maximum abundance values occurred in summer (BARRÍA DE CAO et al., 2005). Chitin is found as a structural material for cyst and lorica walls of some ciliates (GOODAY, 1990; TUNER, 2002). Considering this, and the fact that the proportion of chitin in SPM (w/w) reached $6.8 \%$ in BM and $15.4 \%$ in $\mathrm{CV}$ in the 60-200 $\mu \mathrm{m}$ fraction size, chitin concentration in this fraction in summer might correspond to the highest abundance of ciliates. Also, the small stage of copepods and eggs could contribute with chitin pool in the latter fraction $(60-200 \mu \mathrm{m})$ and season.

The concentration of chitin in the seston fraction of 200-500 $\mu \mathrm{m}$ as well as in seston $>500 \mu \mathrm{m}$, had relevance in $\mathrm{CV}$ and BM during summer (December 2008). The latter corresponded to the proportion of chitin in SPM (w/w), reaching $\sim 28 \%$ and $9 \%(200-500 \mu \mathrm{m})$ and $3.5 \%$ and $1.7 \%$ ( $>500 \mu \mathrm{m})$, in $\mathrm{CV}$ and BM, respectively. Small copepods (Acartia tonsa, Eurytemora americana, among others), cirripedia larvae (Balanus glandula) and crab larvae
(Neohelice granulata), and higher sized zooplankton (e.g. chaetognaths and mysids) are the most common taxa found in BBE (HOFFMEYER, 2004; HOFFMEYER; MIANZAN, 2004). In summer the abundances of $A$. tonsa and the larvae of $N$. granulate were significantly higher, reaching 10869 ind. $\mathrm{m}^{-3}$ in $\mathrm{BM}$ and 2309 ind. $\mathrm{m}$ ${ }^{-3}$ in $\mathrm{CV}$, respectively (DUTTO et al., 2012). Yet, chitin concentration in the seston fraction of 200-500 and $>500$ $\mu \mathrm{m}$, which included the bulk of zooplankton, was low compared to other fractions in this study. Similar chitin values in the size fractions of zooplankton, between 0.02 to $0.05 \mathrm{mg} \mathrm{L}^{-1}$ were registered by LARA et al. (2011).

Zooplankton whose carapaces, exuviae, and fecal pellets contain substantial amounts of chitin (TANG et al., 2010; TUNER, 2002) are an important source of this biopolymer, estimating that the mean annual zooplankton chitin biomass was $26.3 \mathrm{mg} \mathrm{m}^{-3}$ (JEUNIAUX; VOSSFOUCART, 1991). So, the lower concentration of chitin in those two size fraction of seston corresponding to most zooplankton might be the consequence of an efficient break-down process by heterotrophic bacteria such as of chitinolytic Vibrio (LARA et al., 2011; TANG et al., 2010). In this context zooplankton chitin in BBE was present in form of degraded particles contributing to micro-detritus pool in the seston size fraction $<20 \mu \mathrm{m}$.

The largest part of chitin was found in the seston size fraction $<20 \mu \mathrm{m}$, suggesting that nano- phytoplankton, micro-detritus (exuviae and pellets) and other cells (fungi and bacteria), play an important contributing to the chitin pool in BBE. Also POC and SPM were highest in this fraction, stressing its importance for the understanding of chitin dynamics and its link to food web in this estuary.

This work not only is the first report on the amount of chitin in different seston size fractions in the Bahía Blanca estuary but also highlight the possible sources of this polymer in this system. Wider seston spectrum studies and research on the different sources of chitin with emphases on the smaller fraction (fungi and bacteria) are therefore required.

\section{ACKNOWLDGEMENTS}

This work was supported by Deutscher Akademischer Austausch Dienst (German Academic Exchange Service, DAAD) and Consejo Nacional de Investigaciones Científicas y Técnicas (CONICET). The campaigns were supported by the Agencia Nacional de Promoción Científica y Tecnológica (FONCYT-PICT 1713). We are 
grateful to i) IADO boat staff Camilo Bernardez, Enio Redondo, and Alberto Conte for their technical support and help during sampling. ii) Lic. Celeste Lopéz-Abbate and Dra. M. S. Hoffemeyer for their collaboration and support during the sampling period. iii) The staff of the research staff at the Leibniz-Zentrum für Marine Tropenölogie, specially the help of Dorothee Dasbach on the application of specific techniques. Particularly I would like to thank to Dr. Quynh Huong Pham for her support and help during the determination of chitin.

\section{REFERENCES}

ALLDREDGE, A. L.; SILVER, M. W. Characteristic, dynamics and significance of marine snow. Prog. Oceanogr., v. 20, n. 1, p. 41-82, 1988.

ALLDREDGE, A. L.; GOTSCHALK, C. C. The relative contribution of marine snow of different origins to biological processes in coastal waters. Cont. Shelf Res., v. 10, n. 1, p. 41-58, 1990.

ARIAS, A. H.; VAZQUEZ-BOTELLO, A.; TOMBESI, N.; PONCE-VÉLEZ, G.; FREIJE, H.; MARCOVECCHIO, J. Presence, distribution, and origins of polycyclic aromatic hydrocarbons (PAHs) in sediments from Bahía Blanca estuary, Argentina. Environ. Monit. Assess., v. 160, n. 1-4, p. 301-314, 2010.

BALDINI, M. D.; CABEZALI, C. B. Distribución de Echerichia coli en aguas del estuario de Bahía Blanca-Argentina. Rev. Latinoam. Microbiol., v. 30, p. 229-334, 1988.

BALDINI, M. D.; CUBITTO, M. A.; CHIARELLO, M. N.; CABEZALI, C. B. Water quality for aquaculture development in Bahía Blanca estuary, Argentina. Bacteriological studies. Rev. Argent. Microbiol., v. 31, n. 1, p. 19-24, 1999.

BARRÍA DE CAO, M. S.; PETTIGROSSO, R. E.; PARODI, E.; FREIJE, R. H. Abundance and species composition of planktonic Ciliophora from the wastewater discharge zone in the Bahía Blanca Estuary, Argentina. Iheringia, Sér. Zool., v. 93, n. 3, p. 229-236, 2003.

BARRÍA DE CAO, M. S.; BEIGT, D.; PICCOLO, C. Temporal variability of diversity and biomass of tintinnids (Ciliophora) in a southwestern Atlantic temperate estuary. J. Plankton Res., v. 27, n. 11, p. 1103-1111, 2005.

BIANCALANA, F.; MENÉNDEZ, M. C.; BERASATEGUI, A. A.; FERNÁNDEZ-SEVERINI, M. D.; HOFFMEYER, M. S. Sewage pollution effects on mesozooplankton structure in a shallow temperate estuary. Environ. Monit. Assess., v. 184, n. 6, p. 3901-391, 2012.

CABEZALI, C. B.; BALDINI, M. D.; BURGOS, M. A.; ARANGO, J. M. Relationship of physical factors and salinity with indicator bacteria in Bahía Blanca estuary waters, Argentina. Rev. Argent. Microbiol., v. 26, n. 2, p. 59-64, 1994.

DI MAURO, R.; CAPITANIO, F.; VIÑAS, M. D. Capture efficiency for small dominant mesozooplankters (Copepoda, Apendicularia) off Buenos Aires Province $\left(34^{\circ} \mathrm{S}-41^{\circ} \mathrm{S}\right)$, Argentine SEA, using two plankton mesh sizes. Braz. J. Oceanogr., v. 57, n. 3, p. 205-214, 2009.

DIODATO, S. L.; HOFFMEYER, M. S. Contribution of planktonic and detritic fractions to the natural diet of mesozooplankton in Bahía Blanca Estuary. Hidrobiología, v. 614, n. 1, p. 83-90, 2008.
DUTTO, M. S.; LOPEZ ABBATE, M. C.; BIANCALANA, F., BERASATEGUI, A. A.; HOFFMEYER, M. S. The impact of sewage on environmental quality and the mesozooplankton community in a highly eutrophic estuary in Argentina. ICES J. Mar. Sci., v. 69, n. 3, p. 399-409, 2012.

FEDERICI, G. A.; CUADRADO, D. G.; GÓMEZ, E. A. Procesos hidrosedimentológicos y meteorológicos relacionados con la sedimentación de un puerto. Geoacta, n. 29, p. 69-80, 2004.

FERNÁNDEZ-SEVERINI, M. D.; BOTTÉ, S. E.; HOFFMEYER, M. S.; MARCOVECCHIO, J. E. Spatial and temporal distribution of cadmium and copper in water and zooplankton in the Bahía Blanca estuary, Argentina. Estuar. Coast. Shelf Sci., v. 85, n. 1, p. 57-66, 2009.

GOODAY, G. W. Physiology of microbial degradation of chitin and chitosan. Biodegradation, v. 1, n. 2, p. 177-190, 1990.

GUINDER, V. A.; POPOVICH, C. A.; PERILLO, G. M. E. Particulate suspended matter concentrations in the Bahía Blanca Estuary, Argentina: Implication for the development of phytoplankton blooms. Estuar. Coast. Shelf Sci., v. 85, n. 1, p. 157-165, 2009.

HOFFMEYER, M. Decadal change in zooplankton seasonal succession in the Bahía Blanca estuary, Argentina, following introduction of two zooplankton species. J. Plankton Res., v. 26, n. 2, p. 181-189, 2004.

HOFFMEYER, M. S.; BARRÍA DE CAO, M. S. Zooplankton assemblages from a tidal channel in the Bahía Blanca Estuary, Argentina. Braz. J. Oceanogr., v. 55, n. 2, p. 97-107, 2007.

HOFFMEYER, M.; MIANZAN, H. Macrozooplancton del estuario y aguas costeras adyacentes. In: PICCOLO, C.; HOFFMEYER, M. (Eds.). Ecosistema del estuario de Bahía Blanca. Argentina: Sapienza, 2004. p. 143-151.

JEUNIAUX, C.; VOSS-FOUCART, M. F. Chitin biomass and producction in the marine environment. Biochem. Syst. Ecol., v. 19, n. 5, p. 347-356, 1991.

JOHNSTONE, J. Conditions of Life in the Sea. NewYork: Cambridge University Press, 1908.

KIRCHMAN, D. L.; WHITE, J. Hydrolysis and mineralization of chitin in the Delaware Estuary. Aquat. Microb. Ecol., v. 18, n. 2, p. 187-196, 1999.

LARA, R. J.; NEOGII, S. B.; ISLAM, M. S.; MAHMUD, Z. H.; ISLAM, S.; PAUL, D.; DEMOZ, B. B.; YAMASAKI, S.; NAIR, G. B.; KATTNER, G. Vibrio cholerae in waters of the Sundarban mangroves: relationship with biogeochemical parameters and chitin content in seston size fractions. Wetl. Ecol. Manag., v. 19, n. 1, p. 109-119, 2011.

LEE, C.; HOWART, R. W.; HOWES, B. L. Sterols in decomposing Spartina alternijloru and the use of ergosterol in estimating the contribution of fungi to detrital nitrogen. Limnol. Oceanogr., v. 25, n. 2, p. 290-303, 1980.

MENÉNDEZ, M. C.; DUTTO, M. S.; PICCOLO, M. C.; HOFFMEYER, M. S. The role of the seasonal and semi-diurnal tidal cycle on mesozooplankton variability in a shallow mixed estuary (Bahía Blanca, Argentina). ICES J. Mar. Sci., v. 69, n. 3, p. 389-398, 2012.

MENENDEZ, M.; SANMARTI, N. Geratology and descomposition of Spartina versicolor in a brackish Mediterranean marsh. Estuar. Coast. Shelf Sci., v. 74, n. 1-2, p. 320-330, 2007.

MONTGOMERY, M. T.; WELSCHMEYER, N. A.; KIRCHMAN, D. L. A simple assay for chitin: application to sediment trap samples from the subarctic Pacific. Mar. Ecol. Prog. Ser., v. 64, p. 301-308, 1990 . 
NICOL, S.; HOSIE, G. W. Chitin production by kill. Biochem. Syst. Ecol., v. 21, n. 2, p. 181-184, 1993.

PERILLO, G. M. E.; PICCOLO, M. C. Tidal response in the Bahía Blanca estuary, Argentina. J. Coast. Res., v. 7, n. 2, p. 437-449, 1991.

PERILLO, G. M. E.; PICCOLO, M. C.; PARODI, E. R.; FREIJE, R. H. The Bahía Blanca estuary, Argentina. In: SEELIGER, U.; KJERFVE, B. (Eds.). Coastal Marine Ecosystems of Latin America, Ecological Studies. Berlin Heidelberg: Springer, 2001. p. 205-217.

PETTIGROSSO, R. E.; POPOVICH, C. A. Phytoplankton-aloricate ciliate community in the Bahía Blanca Estuary (Argentina): seasonal patterns and trophic groups. Braz. J. Ocenogr., v. 57, n. 3, p. 215-227, 2009.

PICCOLO, M. C. Climatological features of the Bahía Blanca Estuary. In: NEVES, R.; BARETTA, J.; MATEUS, M. (Eds.). Perspectives on Integrated Coastal Zone Management in South America. Lisbon: IST Press, 2008. p. 231-239.

POPOVICH, C. A.; SPETTER, C. V.; MARCOVECCHIO, J. E.; FREIJE, R. H. Dissolved Nutrient Availability during Winter Diatom Bloom in a Turbid and Shallow Estuary (Bahía Blanca, Argentina). J. Coast. Res., v. 24, n. 1, p. 95-102, 2008.

SPETTER, C. V.; POPOVICH, C. A.; ARIAS, A.; ASTEASUAIN, R. O.; FREIJE, R. H.; MARCOVECCHIO, J. E. Role of Nutrients in Phytoplankton Development during a Winter Diatom Bloom in a Eutrophic South American Estuary (Bahía Blanca, Argentina). J. Coast. Res., v. 31, n. 1, p. 76-87, 2015.

SMUCKER, R. A. Chitin Primary Production. Biochem. Syst. Ecol., v. 19, n. 5, p. 357-369, 1991.

SMUCKER, R. A.; DAWSON, R. Products of photosynthesis by marine phytoplankton: chitin in TCA "protein" precipitate. $J$. Exp. Mar. Biol. Ecol., v. 104, n. 1-3, p. 143-152, 1986.
SOUZA, S. P.; ALMEIDA, B. C.; COLWELL, R. R.; RIVERA, I. N. G. The importance of chitin in the marine environment. Mar. Biotechnol. (NY), v. 13, n. 5, p. 823-830, 2011.

STRICKLAND, J. H. D.; PARSONS, T. R. A Practical Handbook of Seawater Analysis. Ottawa: Fisheries Research Board of Canada, 1968.

TANG, K. W., TURK, V.; GROSSART, H. P. Linkage between crustacean zooplankton and aquatic bacteria. Aquat. Microb. Ecol., v. 61, n. 3, p. 261-277, 2010.

TOMBESI, N. B.; PISTONESI, M. F.; FREIJE, R. H. Physico-chemical characterisation and quality improvement evaluation of primary treated municipal waste water in the city of Bahía Blanca (Argentina). Ecol. Environ. Conserv., v. 6, n. 2, p. 147-151, 2000.

TUNER, J. T. Zooplankton fecal pellets, marine snow and sinking phytoplankton blooms. Aquat. Microb. Ecol., v. 27, n. 1, p. 57102, 2002.

VOLKMAN, J. K.; TANOUE, E. Chemical and biological studies of particulate organic matter in the ocean. J. Oceanogr., v. 58 , n. 2, p. 265-279, 2002.

WURZBACHER, C. M.; BÄRLOCHER, F.; GROSSART, H. P. Fungi in lake ecosystems. Aquat. Microb. Ecol., v. 59, n. 2, p. 125-149, 2010.

YOSHIKOSHI, K.; KÔ, Y. Structure and function of the peritrophic membranes of copepods. Nippon Suisan Gakkai Shi., v. 54, n. 7, p. 1077-1082, 1988.

ZOBELL, C. E.; RITTENBERG, S. C. The occurrence and characteristics of chitinoclastic bacteria in the sea. J. Bacteriol., v. 35, n. 3, p. $275-287,1938$. 